\title{
ARTIKEL
}

\section{THE TEACHING READING COMPREHENSION OF HORTATORY EXPOSITION TEXT TO THE ELEVENTH GRADE STUDENTS IN MEDAN}

\section{Disusun dan Diajukan oleh:}

\author{
Nova Marya Simanjuntak \\ NIM. 2123321056
}

\section{Telah diverifikasi dan dinyatakan memenuhi syarat untuk diunggah pada jurnal online}

\section{Medan, Juli 2017}

\section{Menyetujui,}

Dosen Pembimbing Skripsi I

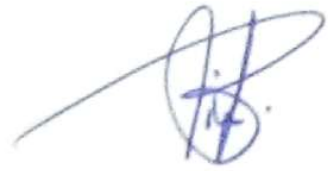

Prof.Dr.Berlin Sibarani,M.Pd NIP. 195706151982031005
Dosen Pembimbing Skripsi II

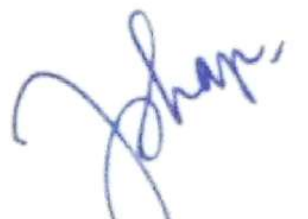

Johannes Jefria Guhtom,S.Pd., M.Hum NIP.19810501 20032 1003

Ka. Program Studi

Pendidikan Bahasa Inggris

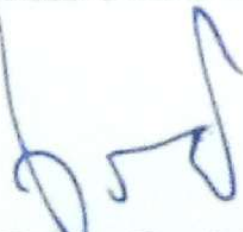

Nora Rontta Dewi, S.Pd., S.S., M.Hum.

NIP. 198005222008122003 


\title{
THE TEACHING READING COMPREHENSION OF HORTATORY EXPOSITION TEXT TO THE ELEVENTH GRADE STUDENTS IN MEDAN
}

\author{
*Nova Marya Simanjuntak \\ ***Prof.Dr.Berlin Sibarani, M.Pd \\ **Johannes Jefria Gultom, S.Pd.,M.Hum
}

\begin{abstract}
Nova Marya Simanjuntak. Registration Number: 2123321056. The Teaching Reading Comprehension of Hortatory Exposition Text to the Eleventh Grade Students in Medan. A Thesis. English Educational Program, State University of Medan, 2016.
\end{abstract}

The objectives of this study were to describe how the teachers teach reading comprehension of hortatory exposition text to the eleventh grade students in Medan and to reveal the underlying reasons why they did that way. This study was conducted by using descriptive qualitative design. The subjects of this study were two English teachers who taught at the eleventh grade students at SMA Methodist 8 Medan in academic year 2016/2017. The data were collected by observing, video recording and interviewing and analyzed by using Miles and Huberman technique (1994). The findings of the study showed that most of the teachers' way are not yet focusing on teaching reading comprehension but rather focusing to the teaching the knowledge of the genre. The underlying reasons of the teachers' ways in teaching reading comprehension did not facilitate reading comprehension. It was due to the misperception of the concept of teaching reading comprehension.

Keywords: teaching, reading comprehension, hortatory exposition text

*Graduate Status

**Lecturer Status 


\section{INTRODUCTION}

\section{Background of the Study}

As an international language, English is used to communicate with all people around the world. In Indonesia English has been taught as a foreign language. The people should master English started from the primary students to the university level. The government, education ministry established English as a compulsory subject in schools so that all students have to learn English. By learning English, the students will comprehend many texts from all over the world to support their learning process. It can be concluded that English has an important role in education. Because of it, people have to learn and master English to face the world globalization.

In English there are 4 skills that should be learnt by the learners. They are speaking, listening, writing and reading. Each skill has the difficulties itself in understanding it. Not only in understanding each skill but also in teaching the skill also has different difficulties. It is different ways to teach speaking, to teach listening, to teach writing and to teach reading.

Teaching is an essential part of education. Teaching has the special function which transfers the knowledge, develops understanding and builds the characteristic and someone's behavior. Gage (2009) argues that teaching is a form of interpersonal influenced aimed at changing the behavior potential of another person. Teaching is not an easy activity to do. The people who do the teaching activity calls teacher and the people who are teach by the teacher normally called students. The process of 
teaching related to transfer the knowledge, develop understanding and skill and to build the characteristic and behavior of someone the teacher must to be qualified and mastery the things related to teaching.

Reading can be challenging, particularly when the material is unfamiliar, technical, or complex, Danielle (2007). When someone read a text, it is not just read the text word by word. They need to comprehend the text deeply to understand what it is said in the text. To get the point, to get the information in the text, the readers are not only read the text word by word but also they need to go beyond the text to get it. The students who like reading will get knowledge and new insight which improve their intelligence so that they are more ready to face life challenge in the future. But all knowledge can't get if it's just reading without reading comprehension or read with deep comprehending the text.

The reality shows that many students are failed in reading comprehension because they are not taught reading well especially in hortatory exposition text. Senior High School Curriculum has been recognizes the act of reading comprehension as part of the language learning process. With regard to a need of the reading comprehension of the students, School Based Curriculum (KTSP) presents a syllabus English subject of Senior High School that entrusts some indicators of successful in teaching reading comprehension. This can be used by the teacher as guidance in the teaching process of reading comprehension to the students. But the reality that some of the teachers usually orients to the students textbook in teaching reading. The teachers just follow the material of the textbook by reading the text 
translating into bahasa indonesia and then answer the questions related to the text. These activities do not give any influence for improving student's ability in reading comprehension because it cannot give contribution to students; it makes the students only passive in the teaching learning process. It means more teachers focus on teaching "reading" not "understanding" or "comprehending" as the consequence and also more teachers just help the students to comprehend the certain text and help them to answer the questions from the text. As a result, the students tend to have poor reading skill and habits or in other word the students cannot be an independent reader. So if the students are given other text, they cannot comprehend the text without their teacher's help. To ensure this idea, this study was conducted with the title of "The Teaching Reading Comprehension of Hortatory Exposition Text to the Eleventh Grade Students in Medan”.

\section{REVIEW OF RELATED LITERATURE}

Klingner (2007:2) defines that reading comprehension as the process of constructing meaning by coordinating a number of complex processes that include word reading, word and word knowledge, and fluency. The meaning construction take place through the coordination's of a number of complex process that conclude word reading, word and word, knowledge and fluency.

Gage (2009:51) states that teaching reading comprehension is happened because there are six variables process in the teaching process, they are (1) presage variable, (2) context variable, (3) teacher thought 
process, (4) process for content of teaching, (5) students thought process, and (6) students achievement.

Klingner (2007:87) states that the term of hortatory exposition text refers to the ways the text is organized to guide readers in identifying the key information and making the connections among ideas. Because by knowing the organization of the structure well the reader will know what happened next in the text. Klingner also asserts that hortatory exposition text structures are more challenging than the other text structure for the students in the process of learning. Also the connection between ideas in hortatory exposition text is not simple sequence of familiar events depicted in the other text structures. Englert \& Hiebert (1984) in Klingner (2007:87) state that when reading hortatory exposition text the students must not only attend the information in the text but also identify the type of the text structure used to present it.

Klingner (2007:76) asserts that when the students are familiar with the way a text is structured, this knowledge can help them (1) form expectations about what they will read, (2) organize incoming information, (3) judge the relative importance of what they read, (4) improve their comprehension, and (5) enhance their recall. However, when the structure of a text is different from what the reader expect, comprehension can break down. Struggling readers are more likely than stronger readers to be unaware of text structures and to experience difficulty using them to help with 
comprehension Yet explicit instruction can help struggling readers become more aware of various text structures and augment their comprehension and memory.

\section{Relevant Studies}

There are several studies about coherence and cohesion in writing in order to get better understanding for researchers and readers. Sri Puspitasari, (2013), was about the students' achievement in writing hortatory exposition text. She analyzed the improvement of the student's ability in writing hortatory exposition text through taba strategy. She decided to research hortatory exposition text because based on her experienced most of the students in the XI Grade have low score in delivering their idea especially in writing the exposition text. After doing the research she found that taba strategy influenced the students' achievement in writing hortatory exposition text.

Novia, (2015), who studied about the teaching reading comprehension of hortatory exposition text. She analyzed the teaching reading comprehension of hortatory exposition text by using skimming and scanning. She decided to analyze the teaching reading comprehension because based on her experience that the students are hard to understand the text when they read the text. She also found that the students are bored and they are not really interested in reading a text especially for a long text. In implementation skimming and scanning also have some advantages and disadvantages for the students. The advantages in implementation skimming and scanning are: the students got the global information from the text with skimming 
technique and the students' can understand the text easily and quickly without using much time. And the disadvantages skimming and scanning are: when the students using skimming and scanning technique they must read quickly. Sometimes there is which sentence is overcome, so if there is question that must finding detailed information, they have to repeat again until twice or more.

Fitria, (2014), the study was also related to the teaching reading comprehension of hortatory exposition text to the students. She analyzed the reading comprehension because mostly of the students nowadays are not really interesting in reading text especially long text. She found that it is hard for the students to construct the meaning from the text especially when they are reading hortatory exposition text.

Nopri, (2015), who studied about improving the student's reading comprehension of hortatory exposition text. Based on her research reading English as a foreign language is not an easy task. Problems are greater and comprehension failure is common. In reading comprehension, they do not only read the symbols but also be able to understand what they read and hortatory exposition text is the most difficult genre which is taught at senior high school is hortatory exposition. It happens during teaching reading at MA Diniyah Puteri for the XI grade. Most of the students have difficulty in constructing meaning as they read from hortatory exposition. The students fail to know the component of hortatory exposition text such as; the purpose of the text, main idea, vocabulary, references, generic structure and also the language features. So, based on those references, this study will analyze the way of teachers teach reading comprehension of hortatory exposition text. 


\section{RESEARCH METHODOLOGY AND FINDINGS}

\section{Methodology}

This study was conducted with descriptive qualitative design which describes and interprets what it is. As Creswell (2007) states that descriptive qualitative research describes the phenomenon being studied, conditions or relationship that exist, processes that are going on or effects that being felt. The data were taken from the teachers' ways in teaching reading comprehension of hortatory exposition text to the students.

\section{Technique of Data Analysis}

Data analysis is a process where researcher systematically searches and arranges the data in order to increase her understanding of it. This research followed some steps of analyzing the data as stated by Miles \& Huberman (1994:10) :

1. Data reduction

Data reduction reduces a large amount of data into a smaller number of analytic units.

2. Data display

Data display is meant as a visual format that presents information systematically. In data display, the data will be organized to answer research problems.

3. Conclusion drawing and verification

Conclusion involves stepping back to consider what the analyzed data mean and to generate their implications for the research question. Verification 
integrally linked to draw conclusion, revisiting the data as many times necessary to cross check or verifies these emergent conclusions. (Miles \& Huberman, 1994).

\section{Research Procedure}

There were several procedures that should be followed in this research:

1. The teachers were recorded in the process of teaching reading comprehension of hortatory exposition text to the students

2. The data recorded were analyzed into formed of tabulation of teacher's teaching process

3. The way the teachers teach reading comprehension of hortatory exposition text was used to answer research problem 1.

4. Doing the interview to the teachers and asked them why they performed the ways in the process of teaching reading comprehension of hortatory exposition text to the students. This was used to answer research problem 2.

\section{CONCLUSIONS AND SUGGESTIONS}

\section{Conclusions}

Some findings are found after analyzing the data. The findings in this research are as follows:

1. The English teacher was teaching reading comprehension to the students by performing 93 total variations of ways and these ways take place into 8 main ways. Based on the content, there 23 ways were 
being performed by the teacher. The ways performed by the teachers are not yet focused on enabling the students to be an independent or skilful reader. Most of the ways are directed the students just to become good at reading text or translating the text into bahasa rather than to tech how to comprehend hortatory exposition text. Most of the ways performed were just focused on translation, vocabulary enrichment, telling idea, pronunciation and managing the class and etc.

2. The underlying reasons of teacher's way in teaching reading comprehension was due to the five reasons, they are; (1) the teacher believed that knowing definition is the very first step to comprehend a text (2) the teacher believed that the theory of the text is facilitative to reading comprehension (3) the teacher believed that translating is facilitative to reading comprehension (4) the teacher believed that answering question is the indicator of text comprehension (5) the teacher believed that the way the students tell their idea in English shows that they comprehend the text

\section{Suggestions}

Based on the above conclusions, there are some suggestions listed:

a). In teaching reading comprehension of hortatory exposition text the teacher should not limit the ways by providing the characteristics of the text only, but also integrate it to the reading comprehension skill of the students 
because those characteristics enabled the students to make their reading comprehension better.

b). The teacher should learn more about the nature of reading comprehension and each teaching method in order that they do not confine the teaching of reading to the teaching of speaking or translating and vocabulary.

c). The knowledge of the teachers in teaching reading comprehension should be improved in order to make them teaching in an appropriate way.

\section{REFERENCES}

Danielle. S 2007. Reading comprehension strategies. Theories, invention and technologies. New York: Lawrence Erlbaum Associates

Gage, N. L. 2009. A Conception of Teaching. New York : LLC

Grabe, William and Stoller, Fredricka R. 2002. Teaching and Researching Reading. New York: Pearson Education

Harmer. J. 2004. The practice of language teaching. London: Longman

Klingner. Janette. K and Sharon Vaughn. 2007. Teaching reading comprehension to the students with learning difficulties. New York: The Guildford Press

Knaap. P., Watkins. M. 2005. Genre, Text, Grammar. Sidney: University of New South Wales Press

Miles. B, Huberman. M. 1994. Qualitatvive data Analyiss. London: Arizona State University

Mikulecky, Beatrice S.1990.A Short Course in Teaching Reading Skills. New York: Addsion Wesley Publishing Company 
Novia. 2015. A study of teaching reading comprehension of hortatory exposition text using skimming and scanning to the eleventh grade students of SMAN 7. Kediri: Universitas Nusantara

Nurhayati, A., \& Aswandi. (2014). Implementing interactive reading model to teaching hortatory exposition text. Journal of UNESA, 01, 1-9.

Pardiyono. 2007. Pasti bisa. Teaching genre-based writing. Yogyakarta: Andi offset

Peterson. A. 1965. Techniques of Teaching. New York: The Department and Institute of Education

Puspita. S. 2013. Improving students' writing achievement in hortatory oxposition text through taba strategy. Medan:UNIMED

Snow, Catherine. 2002. Reading for Understanding: Toward A Research and Development Program in Reading Comprehension.Pittsburgh: RAND.

Westwood, Peter. 2008. What Teachers Need to Know about Reading and Writing Difficulties. Sidney: ACER Press 